\title{
Supervisors Facilitate Principals Teachers in Creating Student Achievements
}

\author{
Chairul Fahmi* \\ Magister of Educational Administration \\ Syiah Kuala University \\ Banda Aceh, Indonesia \\ *fahmitoyotaaceh@gmail.com
}

\author{
Yusrizal, Niswanto \\ School of Educational \\ Syiah Kuala University \\ Banda Aceh, Indonesia \\ yusrizal_fkipunsyiah@yahoo.co.id,niswanto@unsyiah.ac.id
}

\begin{abstract}
This study aims to analyze the role of supervisors' commitment to facilitate school principals and teachers in improving student achievement at 2 state Islamic first high school Tungkop Aceh Besar. The research method used was a descriptive qualitative which was carried out for six months of the study so that the results of the study obtained very in-depth information on 2 state Islamic first high school Tungkop Aceh Besar. Supervision uses methods in accordance with Government regulations on supervisors, namely facilitating, increasing the competence of school principals, teachers in creating highachieving students. The results of this study indicate an increase related to performance, teacher competence facilitated by supervisors, and likewise with student achievement there is a creation of achievement in students due to competent principals and teachers. The conclusion is that creating achievement in students must be through competent principals and teachers and of course this must be facilitated by supervisors, then supervision must be oriented towards increasing competence.
\end{abstract}

Keywords-principals, supervisors, teachers, student achievements

\section{INTRODUCTION}

Education is a fundamental need for a nation or for a country to develop its human resources. Law Number 20 of 2003 concerning the National Education System, articles 5 paragraphs 1 to 4, states that: (a) citizens have the same rights to obtain quality education; (b) citizens with physical, emotional, mental, intellectual and / or social disabilities are entitled to special education; (c) citizens in remote or underdeveloped areas as well as remote communities are entitled to special service education; (d) citizens who have the potential for intelligence and special talents are entitled to special education.

From the statement of the law, it is clear that the regulation and planning of education is proof that the importance of education to a country and the nature of education itself is changing in order to increase the intelligence of the nation's children in the world of education.

In improving the intelligence of the nation's children, of course, those who will be at the forefront of education are professional teachers. Saud [1] states, "Teacher most professionals do not have the characteristics of following it; (1) Having a commitment to the student learning process; (2) Mastering in depth the subject matter and how to teach it; (3) Able to think systematically about what they do and learn from their experiences; and (4) Is part of the learning community in a professional environment that allows them to always improve their professionalism.

Of the four characteristics of teacher professionalism in the above must necessarily owned by a teacher. In achieving what that say in world at the top such as, improving the professionalism of teachers the presence of the role of the supervision is very important. Where the supervisor is partner each of teacher and leader of the school in improving the competence of professional them in order to achieve the purpose of the education that is to make intelligent children of the nation.

Satori [2] states, "The concept of a supervisor is that the supervisor is an administrative function to ensure that the activities carried out are in accordance with what is desired". Suhardan [3] states, "Supervision is an academic activity, which is a supervisory activity that must be carried out by those who have a deep understanding of the activities they supervise". From the two statements of supervision experts in their field, it is said that the purpose of supervision is so that what is the vision and mission of an educational institution can be achieved effectively and efficiently, and those who carry out supervision must have a deep understanding of the expertise and what is will be done.

Therefore, it cannot be denied that the role of supervision in improving the professionalism of school principals is very important to do, so that the output of the education process is to improve and create students who are reliable, accomplished, have faith and devotion to Allah SWT.

\section{RESEARCH METHODS}

The approach used in this study is a qualitative approach. The research used is qualitative research whose data will follow a descriptive formula. According to Sugiyono [4] "The 
formulation of a descriptive problem is a problem formulation that guides researchers to explore and or take pictures of social situations that will be studied thoroughly, broadly and deeply".

From the above statement, it can be explained that what is meant by the formulation of a descriptive problem, the researcher will be directed in research to explore data or conditions in the field while collecting data extensively and in depth. Qualitative research is a method in which the method used to find out a truth is proven not only through the visible results, but how the visible results are produced by the invisible or it can be said that the qualitative method is a method that studies behind what appears to be meaning.

According to Marshal and Rossman in Cresswel [5] Qualitative research involves research to delve into the researcher's setting, researchers enter the world of informants through continuous interaction, looking for informants' meanings and perspectives." This is where the researcher will explain the assumptions of the qualitative research.

In accordance with the above opinion, the main point of this study is the researcher himself because the researcher is a key instrument with triangulation or a combination of several sources. Qualitative research is research that is used to reveal symptoms thoroughly and in accordance with the context by collecting data from natural backgrounds by utilizing researchers as a powerful instrument.

The research and review is based on a complete data search process. Henceforth the data is presented descriptively in the form of words. According to Suryabrata [6] says: "The purpose of descriptive research is to make systematic, factual, and accurate descriptions of the facts and characteristics of a particular population or area".

The location of this research was conducted at 2 state Islamic first high school Tungkop, with research subjects consisting of junior high school supervisors, school principals, and school teachers. The research instrument itself in qualitative is the researcher himself and then assisted by interviews and questionnaires given to research subjects. The data selection itself was done by random sampling.

\section{DisCUSSION RESULTS}

\section{A. Supervisor Programs}

The results showed that the supervisory program in facilitating and facilitating school principals and teachers to improve student achievement was proven to be effective, as evidenced by the presence of high achieving students and teachers who had sufficiently good competence. Supervisors carry out their duties as professionals, where they carry out a function rather than supervision, which is to become facilitators of school principals and teachers in increasing their competence.

Indonesian Education University Lecturer Team of Educational Administration [7] stated, "In essence, educational supervision can be interpreted as professional guidance for teachers". Professional guidance refers to all efforts that provide opportunities for teachers to develop professionally, so that they are more advanced in carrying out their main duties, namely improving and enhancing the student learning process.

Jihad and Yusrizal [8] stated, "There is a significant relationship between principal supervision and teacher performance of 0.722 with indicators of planning, implementing, and following up on the results of teacher supervision, and work motivation and supervision of principals have a significant relationship with teacher performance. $75.3 \%$ with teacher performance indicators: professional competence, pedagogic competence, social competence, and personality competence. While the remaining $24.7 \%$ is influenced by other things. " From this explanation, it shows that the presence of supervisors is very influential on teacher performance, and automatically if the teacher's performance is optimal, the student's achievement will increase. Increasing the ability of students can be seen from the achievements of the students. Then the strategy that can be implemented by touching on the Pedagogic sector.

Rahmayani and Nasir [9] stated, "The strategy for supervisors to improve the pedagogical competence of teachers at Madrasah Ibtidaiyah Negeri Bungcala, Aceh Besar District is to involve school principals, curriculum representatives, senior teachers, Teacher Working Group and team teaching." From this statement, teacher pedagogical competence must also be one of the concerns of supervisors to be noticed and fostered so that it develops in a better direction according to teacher competence.

From the above concept, this is in line with what supervisors and principals do when they supervise the improvement of teacher competence, where in essence they are present as professionals who have deep knowledge of what they are going to do, and they do it from the heart. a clean one.

The supervisory program refers to the regulations set by the government, then the supervisor coordinates it in the field or carries out the program according to what is needed in the field in carrying out its function as a supervisor. Nurmala, et al [10] stated, "The school supervisor supervision program was made in accordance with the identification of obstacles experienced by educators from the analysis of previous supervision results".

\section{B. Implementation of Supervisor Program}

Based on the results of the research, the implementation of the supervision program is carried out every one to two months, sometimes also for urgent needs, the supervisor will attend the school. The implementation of this supervision according to the results of the research conducted by researchers is very effective, this is evidenced by the number of students who excel. Where the student's achievement is the result of the assistance of various parties, especially supervisors, school principals and teachers.

Supervisors carry out the program by conducting school visits in the hope of providing solutions when the principal and 
teachers experience problems in carrying out their respective duties. This is also in accordance with what the principal said, "when I have a problem and need help with the implementation of the program, I or we invite the supervisor to come with the hope of being able to provide a solution". With regard to problems, clinical supervision should be carried out, in which clinical supervision itself has a problem-oriented solution. Salma et al., [11] stated, "The clinical supervision program in Islamic Senior High School Beureunuen is arranged based on problems that arise in the classroom. The program is compiled by the supervisor with the teacher after a request for clinical supervision by the teacher". From the above statement it can be concluded that in every teacher problem, the principal can be resolved together with the supervisor.

Then the success of the school cannot be separated from the leadership ability of the head of the school where researchers found that there are good personality factors possessed by the principal, responsible, always prioritizing togetherness in carrying out activities related to increasing teacher competence. Suryabrata [6] states, "The principal's efforts in implementing academic supervision to improve teacher performance include holding teacher meetings at schools, sending a number of teachers to attend upgrading, requiring all teachers to make lesson plans, and collecting all subsequent evaluation instruments. described in the final evaluation report of learning".

From the research found on school supervisors and principals when they supervised, they made notifications before supervising, then they visited the teacher who would be supervised in class or what is known as class visits, before providing input and direction on the strengths of a teacher. Nurmala et al., [10] stated, "The supervision techniques used by school supervisors state 3 junior high school Wish Jaya, Aceh Besar District are varied, namely individual techniques and group techniques which are implemented by holding individual meetings / talks, class visits, class observations and inter-school visits as well as meetings in the Subject Teacher Deliberation forum".

\section{Continous the Implementation of the Supervisory Program}

Based on the results of the research, it can be concluded that the follow-up is carried out by the supervisor by evaluating the supervisor who said to the follow-up, "We are conducting an evaluation. Once a year there is an evaluation with the principal's performance evaluator, then we will report it to the Ministry of Religion of Aceh Besar, for teachers around month 11 and month 12 with Teacher Performance Appraisal from there we will see what are the shortcomings of teachers, from the results that can be our material for the next year. Problems are also discussed in the supervisory group to find solutions".

Nurmala et al., [10] stated "The feedback (follow-up) was carried out by school supervisors based on the results of notes during the implementation of good academic supervision which carried the strengths and weaknesses of educators". From this statement, it can be concluded that feedback is very important as a measure of the achievement of the various activities and programs that have been implemented. Feedback is also one of the references as material in the evaluation of the implementation or monitoring activities.

From the results of the evaluation, if it is found that Educators who have met / exceeded the standards are given an award in the form of an opportunity to take part in a continuous professional development program and for educators who have not reached the standard they are motivated to improve by jointly determining the solutions to be implemented.

Nurbaiti et a., [12] stated, "Supervisors have attempted the follow-up program by calling teachers who have been supervised to make improvements and guidance with an atmosphere of intimacy." From the statement that in order to follow up, the teacher who has been supervised is called back individually to find in-depth information regarding what is obtained from the results of the supervision carried out, this is intended as a follow-up step in the future.

In addition, through the results of research conducted by researchers, there are still supervisors who are still trapped in the administration, even though this is important, but there are more important things, and it is worrying that if we examine it from an administrative point of view, what is asked of the principal and teachers will not be guaranteed. answer completely and this is often an obstacle in the field which in the future becomes evaluation material

Slameto [13] states, "The obstacles faced by school supervisors in carrying out their duties and functions are related to geographical conditions and inadequate public facilities and infrastructure, lack of supervisors, the number of teachers that must be fostered and lack of intensity of supervision". This statement is one of the obstacles found by researchers in their research, so this will be a serious problem in the future if solutions and solutions are not immediately sought

The problems faced by supervisors from a technical perspective, such as the shortage of supervisors and the distance of schools being supervised are far from each other, must be resolved by issuing policies that are able to resolve the obstacles faced. This is especially what the district and provincial education offices have to accomplish, so that the learning process can be well controlled.

\section{CONCLUSION}

The results showed that the supervisor program in facilitating school principals and teachers to improve student achievement. First, adjusting the vision and mission with the school, becoming a dignified school. High achieving graduates who reflect the integrity that exists in students, not only focus on achievement but on how students have maximum morals.

Implementing the use of the supervisory program in facilitating school principals and teachers to improve student achievement by notifying students and then conducting class visits, after which they provide input regarding what has been said. Its use is to facilitate teachers in improving the competence of school principals and teachers. 
Continuous by school supervisors to improve student achievement is to make assessments in accordance with the provisions, such as evaluations carried out related to the performance of school principals are evaluated once a year and teachers as well, after a new assessment is carried out an evaluation is carried out as a benchmark for the program to be determined for in the future.

\section{REFERENCES}

[1] U.S. Saud, Teacher Professional Development. Bandung: CV. Alfabeta, 2017.

[2] J. Satori, Supervision and Quality Assurance of Education. Bandung: CV. Alfabeta, 2017.

[3] D. Suhardan, Service Professional Supervision in Improving the Quality of Learning in the Era of Regional Autonomy. Bandung: Alfabeta, 2010.

[4] Sugiyono, Educational Research Methods (Quantitative, Qualitative, Combined, R \& D and Educational Research). Bandung: Alfabeta, 2019.

[5] J. Creswell, Research Design Approaches to Qualitative, Quantitative, and Mixed Methodologies. Yogyakarta: Student Library, 2019.

[6] S. Suryabrata, Research methodology. Jakarta: Raja Grafindo Persada, 2012.

[7] Indonesian Education University Lecturer Team of Educational Administration, Education Management. Bandung: CV. Alfabeta, 2017.
[8] M. Jihad and Yusrizal, "The Relationship between Work Motivation and Principal Supervision and Teacher Performance at State Junior High Schools in Babahrot District, Southwest Aceh," Journal of Master of Educational Administration, Graduate School of Syiah Kuala University, vol. 7, no. 1, 2019

[9] Rachmayani, Puree and U. Nasir, "Supervisors Strategy in Increasing Pedagogic Competence in Bunggala District Madrasah Ibtidaiyah, Aceh Besar District," Journal of Master of Educational Administration, Graduate School of Syiah Kuala University, vol. 7, no. 1, 2019.

[10] Nurmala, Puree, and Bahrun, "The Effectiveness of Supervision by Supervisors in Improving the Professional Competence of Natural Science Teachers at SMP Negeri 3 Wish Jaya, Aceh Besar District,"' Journal of Master of Educational Administration, Graduate School of Syiah Kuala University, vol. 7, no. 1, 2019.

[11] P. Salma, Yusrizal and U. Nasir, "Implementation of Clinical Supervision in Improving Teacher Professional Competence at MAN Beureunuen," Journal of Master of Educational Administration, Graduate School of Syiah Kuala University, vol. 6, no. 1, 2018.

[12] Nurbaiti, Yusrizal and Niswanto, "Coordination of Supervisors and Principals in Academic Supervision to Improve Teacher Professional Competence in the Cluster 1 Area of Bakti City, Pidie Regency," Journal of Master of Educational Administration, Graduate School of Syiah Kuala University, vol. 7, no. 1, 2019.

[13] Slameto, "Supervision of Education by School Supervisor," Journal of Management Education Master Management of Education, vol. 3, no. 2, 2016. 